\title{
Distribution of the Val108/158 Met Polymorphism of COMT Gene in the Khasi, Garo, Jaintia Populations of Northeast India
}

Pawlinhun D Phanrang, Sofinia KM Mawkhiew, Erica WM Marboh, Roohollah Sobhani, Leader Langbang, Romita Thounaojam and Kripamoy Aguan*

Department of Biotechnology \& Bioinformatics, Northeastern Hill University, India

Submission: November 14, 2016; Published: May 05, 2017

*Corresponding author: Kripamoy Aguan, Department of Biotechnology \& Bioinformatics, Laboratory of Molecular Biology (Neuroscience), Northeastern Hill University, Shillong-793022, India, Tel: +91-9774072242; Email: kmaguan@gmail.com

\begin{abstract}
Catechol-0-methyltransferase (COMT) transfers methyl group from S-adenosylmethionine to hydroxyl group on dopamine and norepinephrine, thereby, inactivates catecholamine. It has two isoforms S-COMT and MB-COMT. The polymorphism of COMT (rs4680) changes valine to methionine at amino acid position 108 in S-COMT and 158 in MB-COMT. In Met108/158 Met polymorphism COMT enzyme activity is reduced by one-fourth compared to the Val108/158Val. This rs4680 polymorphism is associated with various cognitive disorders, and its frequency differs in populations. The present study determined COMT Val108/158Met polymorphism frequency in Khasi, Garo and Jaintia tribes of Northeast India. We recruited 93 healthy volunteers from these tribes and using their genomic DNA amplified COMT polymorphic site and sequenced the DNA. We observed frequent Valine allele ranged from 53\% (Jaintia) to 56\% (Khasi). Additionally, we analyzed Val108/158Met polymorphism frequency in various ethnic populations of HapMap 1000 genome project and compared that with Khasi, Garo and Jaintia tribes. Interestingly, we found that Val108/158Met genotype and allele frequencies of Jaintia population were significantly different from African, Asian and Caucasian, including Guajarati but not different from Italians of Tuscan. However, Khasi and Garo populations showed significant difference in Val108/158Met polymorphism compared to African and Asian populations but not to Caucasian, including Gujarati.
\end{abstract}

Keywords: Val108/158Met; Polymorphism; COMT gene; Khas; Garo; Jaintia

Abbreviations: ASW(A): African Ancestry in Southwest; USA CEU (C): Utah Residents with North \& Western European Ancestry; CHB (H): Han Chinese in Beijing China ; HD(D): Chinese in Denver, Colorado; COMT: Catechol-O-Methyltransferase; CVD: Cardiovascular Diseases; FP: Forward primer; GIH(G): Gujarati Indians in Houston, Texas; JPT(J): Japanese in Tokyo, Japan; LWK(L): Luhya in Webuye, Kenya; Met: Methionine; MEX(M): Mexican ancestry in Los Angeles; MKK(K): Maasai in Kinyawa, Kenya; PCR: Polymerase Chain Reaction; PFC: Prefrontal Cortex; RP: Reverse Primer; SNP: Single Nucleotide Polymorphism; TSI (T): Tuscan in Italy; Val: Valine; YRI (Y): Yoruba in Ibadan, Nigeria

\section{Introduction}

Catechol-0-methyltransferase (COMT) is one of the major mammalian enzymes involved in the metabolic degradation of catecholamine. The enzyme catalyzes the transfer of a methyl group from S-adenosylmethionine (SAM) to a hydroxyl group on a catechol nucleus (of e.g. dopamine, norepinephrine or catechol estrogen), thereby it inactivates catecholamine and catechol drugs [1-3]. There are two isoforms of COMT with similar catalytic mechanisms but dissimilar cellular localization and substrate affinity: a cytosolic soluble form (S-COMT) and a membrane-bound form (MB-COMT) containing an N-terminal, membrane-anchor region with 50 additional amino acids. The longer form, MB-COMT, is primarily produced by nerve cells in the brain.
COMT is particularly important for the efficient functioning of prefrontal cortex (PFC) of the brain which organizes and coordinates information from other parts of the brain. This region is involved in personality, planning, and inhibition of behaviors, abstract thinking, emotion, and working memory $[4,5]$. In COMT knockout (KO) male mice, dopamine is increased by 2-3-fold in PFC region. Several studies have confirmed that either too little or too much of dopamine in PFC impairs the working and recognition memory [6-10]. Since it is involved in various aspects of cognition, COMT has been studied in details for its genetic variation. The most common variation of the COMT gene is the valine to methionine changes at amino acid position 108 in S-COMT and valine to methionine changes at amino acid position 158 in MB-COMT. In carriers of $\mathrm{Met}^{108} /{ }^{158} \mathrm{Met}$ 
polymorphism COMT enzyme activity is reduced by one-fourth compared to the original $\mathrm{Val}^{108} /{ }^{158} \mathrm{Val}$ allele $[11,12]$. Because of its role in executive functioning, a great deal of association studies has been carried out on the $\mathrm{Val}^{108} /{ }^{158}$ Met polymorphism for its role in cognitive processing, schizophrenia, suicidal behavior, psychotic and affective disorders, as well as in other situations such as smoking and post-menopausal breast cancer risk etc. [13-15].

In subjects homozygous for $\mathrm{Met}^{108} /{ }^{158} \mathrm{Met}$ allele has a higher extracellular dopamine level in PFC region and is associated with improved cognitive performance [16], higher preponderance to panic disorder [17] and diminished muopioid system responses to pain [18]. This has led scientist to propose that carriers of Met ${ }^{108} /{ }^{158}$ Met polymorphism may have a more guarded style of processing information, focusing attention and working memory (worrier strategy) whilst individuals homozygous for $\mathrm{Val}^{108} /{ }^{158} \mathrm{Val}$ present a curiosity driven-explorative behavior, better adaptation under stress and better management of emotion (warrior strategy) [19]. Recently, Hall et al. [20] have observed that women carriers of $\mathrm{Val}^{108} /{ }^{158} \mathrm{Val}$ polymorphism display less CVD incidents compared to the carriers of $\mathrm{Met}^{108} /{ }^{158}$ Met polymorphism. However, upon aspirin administration, a commonly used CVD preventive drug, women carrying $\mathrm{Val}^{108} /{ }^{158} \mathrm{Val}$ polymorphism experience higher rate of CVD than women carrier of Met ${ }^{108} /{ }^{158}$ Met polymorphism [20].

Because of its important role in various aspects of cognition, the allele \& genotype frequency distributions of COMT gene in different races and ethnic populations have been studied to get better insight on the very characteristics of the specific population [19-22]. Val allele frequency is higher in East Asian population (0.7) compared to Europeans (0.4) while South American natives such as Surui, Ticuna and Kartiana have higher $\mathrm{Val}^{108} /{ }^{158} \mathrm{Val}$ allelic frequencies ranging from $0.66,0.81$ and 0.99 , respectively [23]. In the same study, higher frequency of Val allele was observed in African tribes [24]. Corroborating Palmatier et al. [23] study, recent HapMap project release \#28 unveiled a very low Met ${ }^{108} /{ }^{158}$ Met genotype frequencies $(<0.1)$ in African tribes (Yoruba, Maasai \& Luhya) and in East Asian ethnic population (Japanese, Han Chinese and Korean) but relatively higher Met ${ }^{108} /{ }^{158}$ Met genotype frequencies among Gujrati Indians (0.218) in Houston and Europeans in Utah (U.S.A.) (0.248).

Herein we studied the allele and genotype frequencies of COMT allele (rs4680; $\mathrm{Val}^{108} /{ }^{158} \mathrm{Met}$ ) in the ethnic population of Khasi, Garo and Jaintia of Northeastern India. No genetic studies have ever been conducted in these ethnic tribal populations, except genetic origin based on STR \& mtDNA analysis [25]. We show that all these three ethnic populations have quite similar $\mathrm{Met}^{108} /{ }^{158}$ Met genotype frequencies (0.15). However, interestingly Jaintia populations show very low $\mathrm{Val}^{108} /{ }^{158} \mathrm{Val}$ genotype frequency $(0.21)$ than Europeans or any other ethnic groups studied so far.

\section{Materials and Methods}

\section{Subjects}

For the assessment and evaluation of the genotypes and allele frequencies of the Val ${ }^{108} /{ }^{158}$ Met polymorphism in the major ethnic populations of Meghalaya, we randomly recruited a total of 93 healthy individuals from in and around the Northeastern Hill University (NEHU) Campus, Shillong, India. We included 30, 34 and 29 subjects from Khasi, Garo and Jaintia ethnic groups, respectively. The exclusion criteria for these populations were the following: history of substance use \& dependence, history of neurobiological disease, intellectual disability or other concomitant medical ailments, and specifically history of marriages outside of their ethnic community at least within the past five generations.

\section{Description of the populations}

Khasi population: The majority of Khasi population inhabits the state of Meghalaya of Northeastern part of India, however, a small population still lives in neighboring Assam and Bangladesh. It is believed that the Khasi people are related to the Mon-Khmer people of South East Asia [26]. Khasi language belongs to Khmer-Nicobar group of the Austro-Asiatic family of language. The Khasis are matrilineal societies.

Jaintia population: The Jaintia, also known as Pnar or Synteng, are a tribal group in Meghalaya, India. One theory says that the word "Jaintia" is derived from the name of the shrine of Jayanti Devi or Jainteswari, an incarnation of the Hindu goddess Durga. Another theory says that the name is derived via Synteng from Sutnuga, a former settlement; the myth of Jayanti Devi was probably created after the Hinduisation of the Jaintia kingdom.

Garo population: The Garos are indigenous people in Meghalaya and neighboring areas of Bangladesh like Mymensingh, Netrokona and Sylhet, who call themselves A•chikMande (literally "hill people," from a•chik "hill" + mande "people") or simply A•chik or Mande. They are the second-largest tribe in Meghalaya after the Khasi and comprise about a third of the local population. The Garos are one of the few remaining matrilineal societies in the world. The Garos are mainly distributed over the districts of Assam, Meghalaya, and Bangladesh.

\section{Ethics statement}

Following a written and verbal explanation on the objectives of the research, and assurance that their identity and genetic data won't be shared with others, the participants signed an informed consent to participate in the study. They did not receive any economical remuneration. This study was approved by the Institutional Ethics Committee for Human Samples/Participants of the Northeastern Hill University (IECHSP/2015/11).

\section{Genotype assay}

Genomic DNA was extracted from human blood using a Qiagen Flexigene DNA extraction kit. Following primers 


\section{Open Access Journal of Neurology \& Neurosurgery}

(COMT-FP: 5'- TCCTGCTCTTTGGGAGAGGT-3'; COMT-RP: 5'-AACGTGGTGTGAACACC TGGT-3') were designed to amplify COMT gene fragment of 392 bp that contains Va $1{ }^{108} l^{158}$ Met polymorphism. PCR was performed with the respective genomic DNAs of the individuals in a PCR-Thermal machine (Applied Biosystems-2720 Thermal Cycler). The PCR product was electrophoressed in $1.2 \%$ agarose gel, the respective PCR amplified COMT-DNA band was sliced out and the DNA was eluted out of the gel using Qiagen Gel-Extraction Kit. Later, the purified COMT-DNA band was sequenced using both forward and reverse primers that were used for PCR (out-sourced; Xcelerics, India). The sequenced data were aggregated and the COMT Val ${ }^{108} /{ }^{158}$ Met polymorphism status of each individual was established for each sample of Garo, Khasi and Jaintia tribes.

\section{Statistical analysis}

We calculated frequencies and percentage of the genotypes and alleles using SPSS statistical program 11.5. Chi-square homogeneity test was performed to evaluate population vs population differences in genotype and allele frequencies. We used Chi-square statistics to test goodness of fit to the HardyWeinberg equilibrium.

\section{Results}

We show some examples of DNA sequence chromatograms of the sample individuals for Val and Met polymorphisms for COMT gene in Figure 2. Our results for the genotype and allele frequency distributions of $\mathrm{Val}^{108} /{ }^{158} \mathrm{Met}$ polymorphism in the Northeast Indian tribes are shown in Table 1. The distribution of these frequencies followed Hardy-Weinberg equilibrium. In Table 2 we list the genotype and allele frequencies of $\mathrm{Val}^{108} /{ }^{158} \mathrm{Met}$ polymorphism in African, Caucasian and Asian populations curated from HapMap public release \#28 wherein the COMT genotype status was ascertained by whole genome sequencing. Herein the genotype frequencies also do follow the HWE. Table 3 shows $\mathrm{p}$ values for genotype and allele frequencies in Caucasian, Asian and African populations against Northeastern Indian tribes for rs4680 polymorphism. (a)

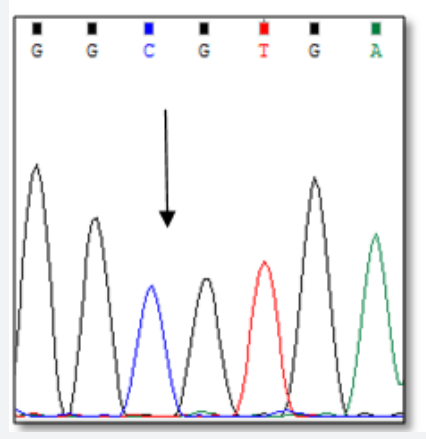

(b)

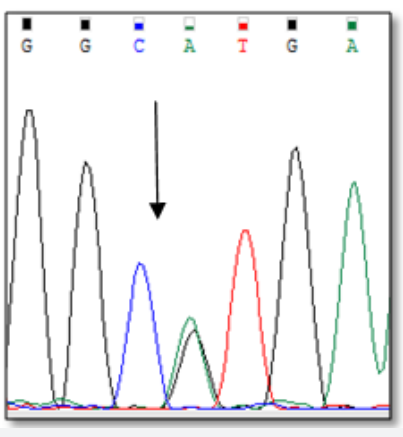

(c)

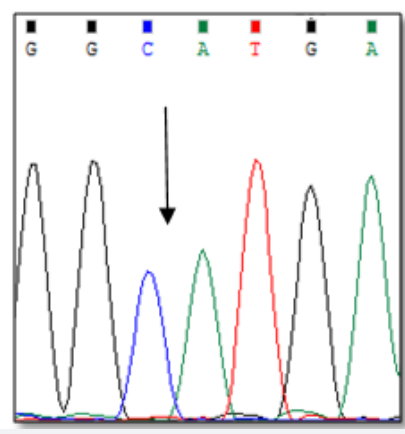

Figure 2: DNA sequence showing chromatograms of Val108/158Met polymorphisms for COMT gene. (a) Homozygote (GG) Val108/158 Val , (b) Heterozygote (GA) Val108/158Met, (c) Homozygote (AA) Met108/158Met.

Table 1: The allele and genotype frequencies of the Val108/158Met polymorphisms for COMT gene in different ethnic population of Meghalaya.

\begin{tabular}{|c|c|c|c|c|c|c|}
\hline Genotype & Frequency & $\mathbf{p}$ & Allele & Frequency & $\mathbf{p}$ & HWE \\
\hline \multicolumn{7}{|c|}{ Khasi population } \\
\hline Met-Met n (\%) & $6(0.2)$ & 0.673 & \multirow{2}{*}{ Met n (\%) } & \multirow{2}{*}{$26(0.433)$} & 0.805 & 0.785 \\
\hline Met-Val n (\%) & $14(0.466)$ & & & & & \\
\hline Val-Val n (\%) & $10(0.333)$ & & \multirow{2}{*}{ Val n (\%) } & \multirow{2}{*}{$34(0.566)$} & & \\
\hline Total & 30 & & & & & \\
\hline \multicolumn{7}{|c|}{ Jaintia population } \\
\hline Met-Met n (\%) & $3(0.103)$ & 0.285 & \multirow{2}{*}{ Met n (\%) } & \multirow{2}{*}{$27(0.465)$} & 0.853 & $0.014^{*}$ \\
\hline Met-Val n (\%) & $21(0.724)$ & & & & & \\
\hline Val-Val n (\%) & $5(0.172)$ & & \multirow{2}{*}{ Val n (\%) } & \multirow{2}{*}{$31(0.534)$} & & \\
\hline Total & 29 & & & & & \\
\hline \multicolumn{7}{|c|}{ Garo population } \\
\hline Met-Met n (\%) & $7(0.206)$ & 0.828 & \multirow{2}{*}{ Met n (\%) } & \multirow{2}{*}{$31(0.456)$} & 0.375 & 0.963 \\
\hline Met-Val n (\%) & $17(0.500)$ & & & & & \\
\hline
\end{tabular}




\section{Open Access Journal of Neurology \& Neurosurgery}

\begin{tabular}{|c|c|c|c|c|c|}
\hline Val-Val n (\%) & $10(0.294)$ & \multirow{2}{*}{ Val n (\%) } & \multirow{2}{*}{$37(0.544)$} & 0.375 & \multirow[t]{2}{*}{0.963} \\
\hline Total & 34 & & & & \\
\hline \multicolumn{6}{|c|}{ Combined } \\
\hline Met-Met n (\%) & $16(0.172)$ & & $84(0.452)$ & & 0.214 \\
\hline Met-Val n (\%) & $52(0.559)$ & & & & \\
\hline Val-Val n (\%) & $25(0.269)$ & & $102(0.548)$ & & \\
\hline Total & 93 & & & & \\
\hline
\end{tabular}

P-value is compared between pooled frequencies (genotype \& allele) vs individual population frequency. *Denotes the value is not consistent with HWE.

Table 2: Comparison of allele and genotype frequencies of COMT gene in Caucasian, Asian and African populations for rs 4680 SNP derived from HapMap 1000 genome project (Release No.\# 28) vs Northeast Indian populations of Khasi, Garo and Jaintia (combined).

\begin{tabular}{|c|c|c|c|c|c|c|c|c|c|c|}
\hline \multirow[t]{2}{*}{ Panel } & \multirow[t]{2}{*}{ Description } & \multirow[t]{2}{*}{$\begin{array}{c}\text { No. of } \\
\text { samples }\end{array}$} & \multicolumn{3}{|c|}{$\begin{array}{c}\text { Genotypic } \\
\text { Frequency }(\%)\end{array}$} & \multirow[t]{2}{*}{$\mathbf{p}$} & \multirow[t]{2}{*}{$\begin{array}{l}\text { Freq. } \\
\text { of } G\end{array}$} & \multirow[t]{2}{*}{$\begin{array}{l}\text { Freq. } \\
\text { of } A\end{array}$} & \multirow[t]{2}{*}{$\mathbf{p}$} & \multirow[t]{2}{*}{ HWE } \\
\hline & & & GG & GA & AA & & & & & \\
\hline $\operatorname{ASW}(\mathrm{A})$ & $\begin{array}{c}\text { African } \\
\text { ancestry in } \\
\text { Southwest } \\
\text { USA }\end{array}$ & 57 & 0.57933 & 0.29817 & $\begin{array}{c}0.123 \\
7\end{array}$ & 0.0007 & 0.73 & 0.27 & 0.001 & 0.10 \\
\hline CEU (C) & $\begin{array}{c}\text { Utah } \\
\text { residents } \\
\text { with North } \\
\text { \& Western } \\
\text { European } \\
\text { ancestry }\end{array}$ & 113 & 0.29233 & 0.46052 & 0.24828 & 0.29 & 0.52 & 0.48 & 0.60 & 0.439 \\
\hline CHB (H) & $\begin{array}{l}\text { Han Chinese } \\
\text { in Beijing, } \\
\text { China }\end{array}$ & 137 & 0.52672 & 0.37251 & 0.10214 & 0.0006 & 0.71 & 0.29 & 0.0003 & 0.752 \\
\hline CHD (D) & $\begin{array}{l}\text { Chinese } \\
\text { in Denver, } \\
\text { Colorado }\end{array}$ & 108 & 0.51956 & 0.43547 & 0.0465 & 0.0002 & 0.74 & 0.26 & 0.0001 & 0.10 \\
\hline GIH (G) & $\begin{array}{l}\text { Gujarati } \\
\text { Indians in } \\
\text { Houston, } \\
\text { Texas }\end{array}$ & 101 & 0.35636 & 0.42643 & 0.21822 & 0.178 & 0.57 & 0.43 & 0.678 & 0.15 \\
\hline JPT (J) & $\begin{array}{l}\text { Japanese } \\
\text { in Tokyo, } \\
\text { Japan }\end{array}$ & 112 & $\begin{array}{c}0.482 \\
54\end{array}$ & $\begin{array}{c}0.455 \\
51\end{array}$ & $\begin{array}{c}0.062 \\
7\end{array}$ & 0.002 & 0.71 & 0.29 & 0.0007 & 0.655 \\
\hline LWK (L) & $\begin{array}{l}\text { Luhya in } \\
\text { Webuye } \\
\text {,Kenya }\end{array}$ & 109 & 0.49554 & 0.42246 & 0.0839 & 0.003 & 0.71 & 0.29 & 0.001 & 1.00 \\
\hline $\begin{array}{l}\text { MEX } \\
(\mathrm{M})\end{array}$ & $\begin{array}{c}\text { Mexican } \\
\text { ancestry in } \\
\text { Los Angeles }\end{array}$ & 58 & 0.41424 & 0.44826 & $\begin{array}{c}0.138 \\
8\end{array}$ & 0.18 & 0.64 & 0.36 & 0.125 & 1.00 \\
\hline $\begin{array}{l}\text { MKK } \\
(\mathrm{K})\end{array}$ & $\begin{array}{l}\text { Maasai in } \\
\text { Kinyawa, } \\
\text { Kenya }\end{array}$ & 155 & 0.54284 & 0.37458 & $\begin{array}{c}0.084 \\
13\end{array}$ & 0.0001 & 0.73 & 0.27 & $0.000>$ & 0.403 \\
\hline TSI (T) & $\begin{array}{l}\text { Tuscan in } \\
\text { Italy }\end{array}$ & 102 & $\begin{array}{l}0.29430 \\
0.51052\end{array}$ & 0.51052 & $\begin{array}{c}0.196 \\
20\end{array}$ & 0.784 & 0.55 & 0.45 & 1 & 1.00 \\
\hline YRI (Y) & $\begin{array}{l}\text { Yoruba in } \\
\text { Ibadan, } \\
\text { Nigeria }\end{array}$ & 147 & $\begin{array}{c}0.476 \\
70\end{array}$ & $\begin{array}{c}0.422 \\
62\end{array}$ & $\begin{array}{c}0.102 \\
15\end{array}$ & 0.005 & 0.69 & 0.31 & 0.002 & 0.655 \\
\hline \multicolumn{2}{|c|}{ TOTAL } & 1199 & & & & & & & & \\
\hline & $\begin{array}{c}\text { Khasi } \\
\text { population }\end{array}$ & 30 & 0.45 & 0.40 & 0.15 & & 0.65 & 0.35 & & 0.59 \\
\hline & population & & & & & & & & & \\
\hline
\end{tabular}




\section{Open Access Journal of Neurology \& Neurosurgery}

\begin{tabular}{|l|l|l|l|l|l|l|l|l|l|l|}
\hline & $\begin{array}{c}\text { Jaintia } \\
\text { population }\end{array}$ & 29 & 0.21 & 0.63 & 0.15 & & 0.53 & 0.47 & 0.245 \\
\hline $\begin{array}{c}\text { Garo } \\
\text { population }\end{array}$ & 34 & 0.40 & 0.45 & 0.15 & & 0.63 & 0.37 & 0.86 \\
\hline & Combined & 93 & 0.27 & 0.56 & 0.17 & & 0.55 & 0.45 & & \\
\hline
\end{tabular}

Table 3: Comparative table showing the $p$ values for genotype and allele frequencies of COMT gene in Caucasian, Asian and African populations for rs4680 SNP derived from HapMap 1000 genome project (Release No.\# 28) vs Khasi, Garo and Jaintia populations.

\begin{tabular}{|c|c|c|c|c|c|c|c|}
\hline & & \multicolumn{2}{|c|}{ Khasi } & \multicolumn{2}{|c|}{ Garo } & \multicolumn{2}{|c|}{ Jaintia } \\
\hline \multicolumn{2}{|c|}{ Population } & Genotype & Allele & Genotype & Allele & Genotype & Allele \\
\hline ASW (A) & $\begin{array}{c}\text { African } \\
\text { ancestry in } \\
\text { Southwest USA }\end{array}$ & 0.093 & 0.031 & 0.031 & 0.011 & 0.0005 & 0.011 \\
\hline $\mathrm{CEU}(\mathrm{C})$ & $\begin{array}{l}\text { Utah resident } \\
\text { with Northern } \\
\text { and Western } \\
\text { European } \\
\text { ancestry from } \\
\text { CEPH collection }\end{array}$ & 0.834 & 0.538 & 0.869 & 0.750 & 0.038 & 0.867 \\
\hline CHB (H) & $\begin{array}{c}\text { Han Chinese in } \\
\text { Beijing, China }\end{array}$ & 0.112 & 0.029 & 0.038 & 0.008 & 0.0013 & 0.008 \\
\hline GIH (G) & $\begin{array}{l}\text { Chinese in } \\
\text { Metropolitan } \\
\text { Denver, } \\
\text { Colorado }\end{array}$ & 0.013 & 0.011 & 0.004 & 0.003 & 0.004 & 0.003 \\
\hline GIH (G) & $\begin{array}{c}\text { Gujarati Indians } \\
\text { in Houston, } \\
\text { Texas }\end{array}$ & 0.924 & 0.974 & 0.733 & 0.717 & 0.018 & 0.637 \\
\hline JPT (J) & $\begin{array}{l}\text { Japanese in } \\
\text { Tokyo, Japan }\end{array}$ & 0.049 & 0.035 & 0.020 & 0.011 & 0.011 & 0.011 \\
\hline LWK (L) & $\begin{array}{c}\text { Luhya in } \\
\text { Webuye, Kenya }\end{array}$ & 0.108 & 0.0405 & 0.044 & 0.013 & 0.007 & 0.013 \\
\hline $\operatorname{MEX}(M)$ & $\begin{array}{l}\text { Mexican } \\
\text { ancestry in } \\
\text { Los Angeles, } \\
\text { California }\end{array}$ & 0.662 & 0.357 & 0.458 & 0.209 & 0.043 & 0.188 \\
\hline MKK (K) & $\begin{array}{c}\text { Massai in } \\
\text { Kinyawa, Kenya }\end{array}$ & 0.049 & 0.012 & 0.014 & 0.002 & 0.0009 & 0.003 \\
\hline TSI (T) & Tuscan in Italy & 0.902 & 0.809 & 0.991 & 0.944 & 0.121 & 0.845 \\
\hline YRI (Y) & $\begin{array}{c}\text { Yoruban in } \\
\text { Ibadan, Nigeria }\end{array}$ & 0.196 & 0.071 & 0.086 & 0.025 & 0.007 & 0.024 \\
\hline
\end{tabular}

\section{Discussion}

The premise of this present study was to estimate allele and genotype frequencies of $\mathrm{rs} 4680$ SNP $\left(\mathrm{Val}^{108} /{ }^{158}\right.$ Met polymorphism) in the tribes of Northeast India. In rs4680, the Val-allele displays higher COMT activity while Met-allele has only 25-30\% COMT activity that of Val-allele. Several pioneering studies have already established that rs4680 SNP $\left(\mathrm{Val}^{108}\right)^{158}$ Met) is intimately involved in vast array of neurobiological diseases such as cognitive processing, schizophrenia, suicidal behavior, alcohol dependence, smoking etc. Of late, observation by Hall et al. [20] that although $\mathrm{Val}^{108} /{ }^{158} \mathrm{Val}$ women have lower rate of CVD incidents compared to Met108/158Met carrier, upon aspirin administration, a commonly used CVD preventive drug, $\mathrm{Val}^{108} /{ }^{158} \mathrm{Val}$ women experience higher rate of CVD than Met $^{108} /{ }^{158}$ Met carrier, reflects how information on COMT rs4680 allele status can be of life-saving [20]. Therefore, studies on the rs4680-SNP status in the tribes of Northeast India is not only an intellectual exercise in itself but also relevant from the point of genomic medicine approach to the public health policies.

Figure 1 shows the map of the sate Meghalaya, India and location of the three major tribes (Khasi, Garo and Jaintia) in various regions. In the inset of Figure 1, genotype frequencies are shown for individual tribes. The genotype and allele frequencies observed in the three populations are shown in Table 1. The Val \& Met alleles were distributed roughly in equal proportion in these three tribes. Val-allele frequencies were $56 \%, 54 \%$, \& $53 \%$ while Met-allele frequencies were $43 \%, 45 \%$ \& $46 \%$ in Khasi, Garo and Jaintia tribes, respectively. Although, Val-allele 


\section{Open Access Journal of Neurology \& Neurosurgery}

frequency was slightly higher compared to Met-allele, in all the tribes, they were not statistically significantly different. The genotype frequencies of rs4680 SNP in Khasi and Garo tribes do follow Hardy-Weinberg equilibrium (HWE) whereas, in Jaintia tribes, the rs4680-genotype frequency is not consistent with HWE. When the combined genotype and allele frequencies were compared with genotype and allele frequencies of individual ethnicity, no significant differences were observed (Table 1).

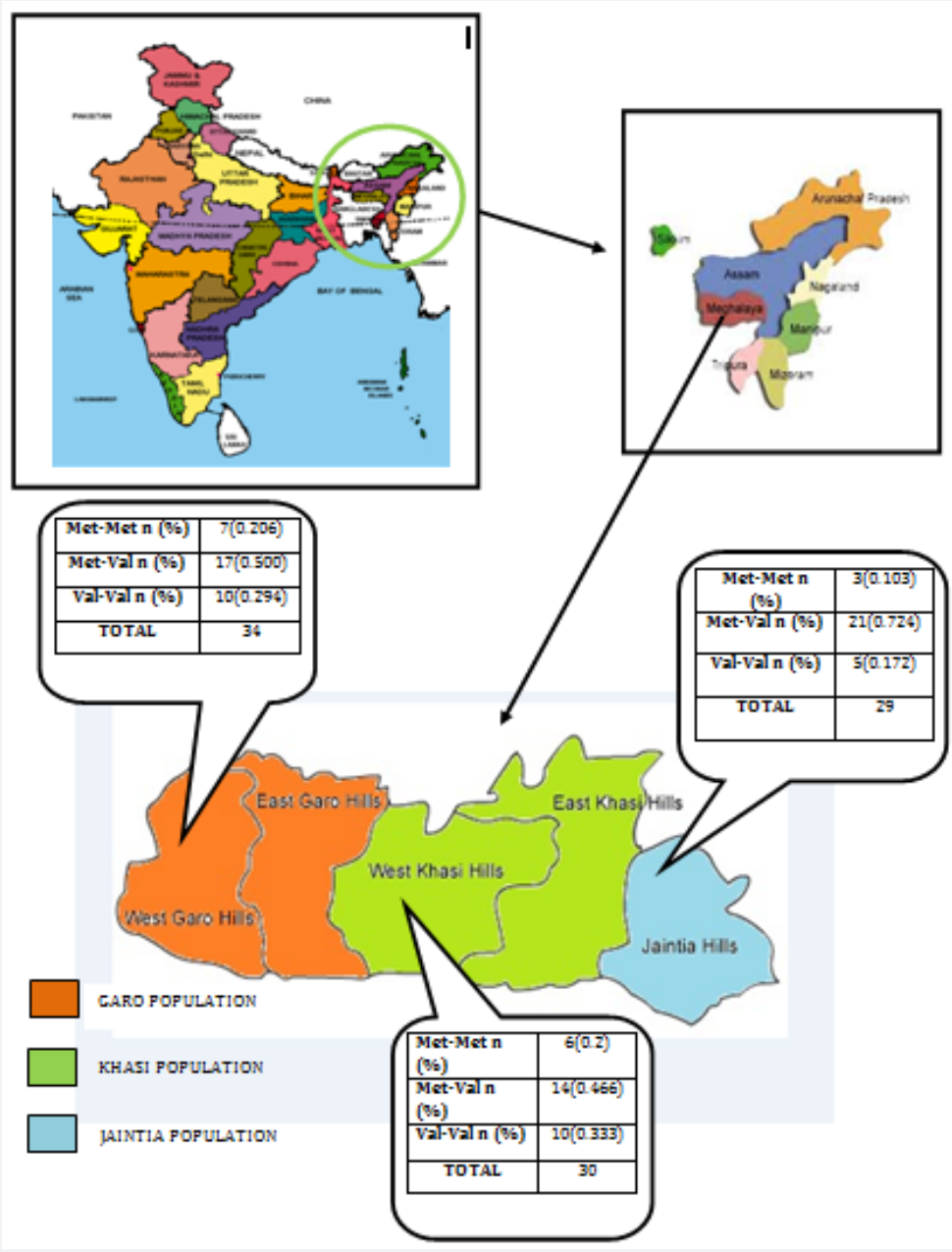

Figure 1: Map of Meghalaya state in India showing the respective genotype frequencies of Val108/158Met polymorphism in the three ethnic populations; Khasi, Garo and Jaintia.

We also compared allele and genotype frequencies of $\mathrm{Val}^{108} /{ }^{158}$ Met polymorphisms in these Northeast Indian tribes with those reported in International HapMap 1000 genome Project release \#28 for other populations such as Caucasian, Asian, and African. In this HapMap release, about 1200 healthy subjects across various ethnicity around the world was sequenced and the genotype and allele frequencies for rs4860 ((Val108/158 Met) SNP were ascertained. The Met-allele and Val-allele frequencies in Caucasian populations (HapMap release \#28) were $48 \%$ and 52\%, respectively. Recently, Gonzalez-castro et al. [27] curated and combined various studies and reported that the Met-allele frequency was higher (54\%) than Val-allele frequency $(46 \%)$ in Caucasian. However, allele frequencies between Gonzalez-castro et al. [27] vs HapMap studies were not significantly different as per our statistical test. In Asian populations (HapMap release \#28), Japanese and Chinese show nearly same Met-allele and Val-allele frequencies-; $27.5 \%$ and $72.5 \%$ vs $29 \%$ and $71 \%$ respectively. The curated data of Gonzalez-castro et al. [27] shows similar allele frequency (29\% \& $71 \%$ for Met- \& Val-allele, respectively). In African, the HapMap release\#28 data shows Met-\& Val-allele frequencies of $71.5 \%$ and $28.5 \%$, respectively, while Gonzalez-castro et al. [27] study shows $67 \%$ \& 34\%, respectively; however, again the difference in allele frequency was not significant. Considering that most of these curated studies as reported by Gonzalez-castro et al. [27] genotyped the status of polymorphism using allele-specific oligo-PCR or allele-specific hybridization, the allele frequencies were not at all different compared to HapMap release \#28, wherein status of genotype was confirmed by sequencing.

We find that combined frequencies of $\mathrm{Val}^{108} /{ }^{158} \mathrm{Met}$ polymorphism (either genotypes or alleles) of Khasi, Garo \& Jaintia were significantly different compared to Asian (Japanese, 


\section{Open Access Journal of Neurology \& Neurosurgery}

Chinese) and African (Table 2). However, these combined frequencies were not different from either Caucasian, Mexicans in Los Angeles, Italians of Tuscan or Gujrati of India origin (Table 2). We further compared genotype and allele frequencies of $\mathrm{Val}^{108} /{ }^{158} \mathrm{Met}$ polymorphism of individual tribal population (Khasi, Garo \& Jaintia) with all the population studied in HapMap project (Release\# 28). Interestingly, here we found that $\mathrm{Val}^{108} /{ }^{158}$ Met genotype and allele frequencies of Jaintia population were significantly different compared to the African, Asian and Caucasian, including Guajarati of Indian origin but not different from Italians of Tuscan (Table 3). Overall, Khasi and Garo populations showed significant difference in $\mathrm{Val}^{108} /{ }^{158} \mathrm{Met}$ polymorphism compared to African and Asian populations but not to Caucasian, including Gujarati (Table 3).

We do acknowledge that there are some limitations in our study as samples number were not really high. A much higher number of these tribal populations should have been studied for definitive conclusion of rs4680 SNP frequency, particularly for Jaintia tribes as $\mathrm{Val}^{108} /{ }^{158} \mathrm{Met}$ polymorphism frequency in them is different from rest of the world populations, except Italians of Tuscan. However, as we sequenced this very polymorphic site in our study, whatever information we got on the $\mathrm{Val}^{108} /{ }^{158} \mathrm{Met}$ polymorphism status, it is inviolable.

\section{Conclusion}

In summary, the distribution of $\mathrm{Val}^{108} /{ }^{158}$ Met polymorphism distinctly distinguishes the three ethnic populations of Northeast India from rest of the Asian population, including, African. Specially, the Jaintia population stands apart from Khasi and Garo populations and from rest of the world population except from Italians of Tuscan. As particular combinations of alleles of $\mathrm{Val}^{108} /{ }^{158} \mathrm{Met}$ are associated with the development of different diseases, especially, recent revelation that beneficial role of aspirin in CVD is dependent on the allele status of Val ${ }^{108} /{ }^{158} \mathrm{Met}$ polymorphism; hence the understanding on the distribution of these alleles might be helpful in providing effective health care services to the respective communities.

\section{Acknowledgement}

The authors acknowledge the kind consent provided by the individuals participated in this study. The work was done with the generous funding from DBT, Govt. of India, Project sanction Number \# 102/IFD/SAN/PR1521/2010-2011.

\section{References}

1. Axelrod J (1957) O-Methylation of Epinephrine and Other Catechols in vitro and in vivo. Science 126(3270): 400-401.

2. Mannisto PT, Kaakkola S (1999) Catechol-O-methyltransferase (COMT): biochemistry, molecular biology, pharmacology and clinical efficacy of the new selective COMT inhibitors Pharmacol Rev 51(4): 593-628.

3. Tai CH, Wu RM (2002) Catechol-O-methyltransferase and Parkinson's disease. Acta Med Okayama 56(1): 1-6.
4. Kimoto S, Muraki K, Toritsuka M, Mugikura S, Kajiwara K, et al. (2012) Selective overexpression of Comt in prefrontal cortex rescues schizophrenia-like phenotypes in a mouse model of 22q11 deletion syndrome. Translational Psychiatry 2(8): e146.

5. Tunbridge AM, Farrell SM, Harrison PJ, Mackay CE (2013) Catechol-Omethyltransferase (COMT) influences the connectivity of the prefrontal cortex at rest. NeuroImage 68: 49-54.

6. Gogos JA, Morgan M, Luine V, Santha M, Ogawa S, et al. (1998) CatecholO-methyltransferase-deficient mice exhibit sexually dimorphic changes in catecholamine levels and behavior. Proc Natl Acad Sci 95(17): 9991-9996.

7. Moron JA, Brockington A, Wise RA, Rocha BA, Hope BT (2002) Dopamine uptake through the norepinephrine transporter in brain regions with low levels of the dopamine transporter. evidence from knock-out mouse lines. J Neurosci 22(2): 389-395.

8. Miner LH, Schroeter S, Blakely RD, Sesack SR (2003) Ultrastructural localization of the norepinephrine transporter in superficial and deep layers of the rat prelimbic prefrontal cortex and its spatial relationship to probable dopamine terminals. J Comp Neurol 466(4): 478-494.

9. Tunbridge E, Burnet PW, Sodhi MS, Harrison PJ (2004) Catecholo-methyltransferase (COMT) and proline dehydrogenase (PRODH) mRNAs in the dorsolateral prefrontal cortex in schizophrenia, bipolar disorder, and major depression. Synapse 51(2): 112-118.

10. Papaleo F, Crawley JN, Song J, Lipska BK, Pickel J, et al. (2008) Genetic dissection of the role of catechol-0-methyltransferase in cognition and stress reactivity in mice. J Neurosci 28(35): 8709-8723.

11. Chen J, Barbara K Lipska, Nader Halim, Quang D Ma, Mitsuyuki Matsumoto, et al. (2004) Functional analysis of genetic variation in catechol-0-methyltransferase (COMT): effects on mRNA, protein, and enzyme activity in postmortem human brain. Am J Hum Genet 75(5): 807-821.

12. Farrell SM, Tunbridge EM, Braeutigam S, Harrison PJ (2012) COMT Val Met genotype determines the direction of cognitive effects produced by catechol-0-methyltransferase inhibition. Biol Psychiatry 71(6): 538-544.

13. Ladislav Hosak (2007) Role of the COMT geneVal158Metpolymorphism in mental disorders: A review. European Psychiatry 22(5): 276-281.

14. Wedren S, Rudqvist TR, Granath F, Weiderpass E, Ingelman-Sundberg M, et al. (2003) Catechol-0-methyltransferase gene polymorphism and post-menopausal breast cancer risk. Carcinogenesis 24(4): 681-687.

15. Omidvar M, Stolk L, Uitterlinden AG, Hofman A, Van Duijn, et al. (2009) The effect of catechol-0-methyltransferase Met/Val functional polymorphism on smoking cessation: retrospective and prospective analyses in a cohort study. Pharmacogenet Genomics 19(1): 45-51.

16. Malhotra AK, Kestler LJ, Mazzanti C, Bates JA, Goldberg T, et al. (2002) A functional polymorphism in the COMT gene and performance on a test of prefrontal cognition. Am J Psychiat 159(4): 652-654.

17. Woo JM, Yoon KS, Yu BH (2002) Catechol O-methyltransferase genetic polymorphism in panic disorder. Am J Psychiat 159(10): 1785-1787.

18.Zubieta JK, Heitzeg MM, Smith YR, Bueller JA, Xu K, et al. (2003) COMT val158-to-met genotype affects mu-opioid neurotransmitter responses to a pain stressor. Science 299(5610): 1240-1243.

19. Stein DJ, Newman TK, Savitz J, Ramesar R (2006) Warriors versus worriers: the role of COMT gene variants 11: 745-748.

20. Hall KT, Nelson CP, Davis RB, Buring JE, Kirsch I, et al. (2014) Polymorphisms in catechol-0-methyltransferase modify treatment effects of aspirin on risk of cardiovascular disease 34(9): 2160-2167. 
21. Al Hendy, Salama SA (2006) Catechol-0-methyltransferase polymorphism is associated with increased uterine leiomyoma risk in different ethnic groups. J Soc Gynecol Investig 13(2): 136-144.

22. Chandrasekhar T, Menom R, Wentz MJ, Fortunato SJ, Bartlett J, et al (2012) A single-nucleotide polymorphism in the fetal catechol-Omethyltransferase gene is associated with spontaneous preterm birth in African Americans. Reproductive Sciences 19: 135-142.

23. Palmatier MA, Kang AM, Kidd KK (1999) Global variation in the frequencies of functionally different catechol-0-methyltransferase alleles. Biol Psychiatry 46(4): 557-567.

24. The International HapMap Consortium (2010) Integrating common and rare genetic variation in diverse human populations. Nature 467(7311): 52-58.

This work is licensed under Creative

Commons Attribution 4.0 Licens

http://dx.doi.org/10.19080/OAJNN.2017.03.555620
25. Reddy BM, Langstieh BT, Kumar V, Nagaraja T, Reddy AN, et al. (2007) Austro-asiatic tribes of Northeast India provide hitherto missing genetic link between South and Southeast Asia. PLoS One 2(11): e1141.

26. Schmidt Wilhelm (1906) Die Mon-Khmer Voelker, ein Bindeglied zwischen Voelkern Zentralasiens und Austronosiens 5: 59-109.

27. Gonzalez-Castro TB, Tovilla Zarate C, Juarez Rojop I, Pool Garcia S, Genis A, et al. (2013) Distribution of the Val108/158Met polymorphism of the COMT gene in healthy Mexican population 526(2): 454-458.

\section{Your next submission with Juniper Publishers} will reach you the below assets

- Quality Editorial service

- Swift Peer Review

- Reprints availability

- E-prints Service

- Manuscript Podcast for convenient understanding

- Global attainment for your research

- Manuscript accessibility in different formats

( Pdf, E-pub, Full Text, Audio)

- Unceasing customer service

Track the below URL for one-step submission https://juniperpublishers.com/online-submission.php 